\title{
Recensão/Review
}

\section{Leopoldina Maria Souza de Araújo, 2002, Cantos de caçador: povo Parkatêjê - Pará. Belém: Instituto de Artes do Pará. 55p.}

Áustria Rodrigues Brito ${ }^{1}$

A autora constrói, com muita habilidade, uma antologia de cantos tradicionais do povo Parkatêjê, "Cantos de Caçador", em que se evidenciam as principais características das cantigas de caçador desse povo. São manifestações culturais provenientes de um conhecimento tradicional, que tem por finalidade explicar práticas e concepções míticas relacionadas aos animais. Anunciam a chegada do caçador com ou sem a caça. O depoimento de Krôhôkrenhûm, capitão da aldeia Parkatêjê, revela à autora², o seu grande pesar em relação ao seu povo, por este não demonstrar mais interesse pela prática e exercício dos cantos. Como podemos observar no relato que segue, apresentado no livro (em língua nativa e em Português): "Pois é, Katy, eu concordo com isso. Eu sei que o único é eu mesmo, eu não tenho uma pessoa no meu lado, certo. (...) Como você está vendo, eu quero fazer junto, mas ninguém quer trabalhar comigo. Só eu tenho as cantigas e estou muito com vontade de fazer." (Araújo 2005:3).

Fica evidente que o chefe da comunidade deseja garantir a continuidade da tradição cultural do seu povo. As cantigas reunidas no livro apresentam uma introdução, constituída de um ou dois versos, repetidos, que definem o tema; um ipirã da aldeia Parkatêjê, geralmente constituído por três ou quatro versos, que indica a expansão do tema; uma conclusão, que repete a introdução. As músicas são apresentadas em Parkatêjê, Português, Inglês, Espanhol e Francês.

\footnotetext{
${ }^{1}$ Doutoranda em Linguística, Laboratório de Línguas Indígenas (LALI), Universidade de Brasília.

2 Professora doutora aposentada da Faculdade de Letras da Universidade Federal do Pará (UFPA). Introduziu os estudos das línguas Indígenas naquela universidade, formou várias gerações de alunos que posteriormente se dedicaram ao estudo linguístico dessas línguas. É autora de vários trabalhos acadêmicos e pedagógicos sobre a língua, a cultura e a educação do povo Parkatêjê, junto ao qual desenvolve pesquisa desde 1974 .
} 
Os cantos como um todo revelam o espaço biossocial em que vivem os Parkatêjê: há referências a pessoas, animais, paisagens e acontecimentos; e as músicas são entoadas em tom lírico ou satírico. No livro são reunidos 24 cantos: Pàtàre-Tamanduá 1 e 2; Kapràn-Jabuti 1 e 2; Tônti-Tatu $15 \mathrm{Kg} 1$ e 2; Caçador sem caça 1 e 2; Kukryt-Anta 1 e 2; Kra-Paca 1 e 2; Prỉnti-Piquiá; Kypyt-Guariba 1 e 2; Mire-jacaré 1 e 2; Krỳire-Curica; Jaxy-Veado 1 e 2; Kaputi-Azulão 1 e 2; Kukênêre-Cutia 1 e 2.

A maior parte dos cantos trata de animais que são objeto de caça. Eles ganham descrições geniais, como no canto "Kapràn-Jabuti 1", por exemplo, em que o casco do jabuti é descrito como "cama redonda"; no canto "KukrytAnta 1", a anta é descrita como " pés pesados, mas corre", onde o termo "mas" funciona como operador disjuntivo, acentuando, desta forma, uma característica marcante deste animal.

O narrador conta a história de forma que, em certos momentos, tem-se a certeza de que ele está sentado à sua frente conversando, gesticulando e explicando cada detalhe dos acontecimentos.

\section{Referências}

Coelho, Vera Penteado. 1988. Informações sobre um instrumento musical dos índios Waurá. Revista do Museu Paulista, 33:193-224. São Paulo. 